\title{
STUDI KOMPARATIF TINGKAT KEUNTUNGAN (PROFITABILITAS) USAHATANI CABAI RAWIT LOKAL DAN CABAI RAWIT HIBRIDA DI DESA GAMBANGAN KECAMATAN MAESAN KABUPATEN BONDOWOSO JAWA TIMUR 2017
}

\author{
Muhammad Fadlilah, Lulup Endah tripalupi, I Nyoman Sujana \\ Jurusan Pendidikan Ekonomi \\ Universitas Pendidikan Ganesha \\ Singaraja, Indonesia
}

\begin{abstract}
e-mail: sucipto.muhammadfadlilah@yahoo.co.id, lulup.tripalupi@yahoo.com, sujanatbn@yahoo.com
\end{abstract}

\begin{abstract}
Abstrak
Penelitian ini bertujuan untuk mengetahui jumlah tingkat keuntungan jenis cabai rawit lokal dan hibrida serta perbedaaan tingkat keuntungan jenis cabai rawit lokal dan cabai rawit hibrida bagi usahatani. Jenis penelitian ini merupakan penelitian deskriptif komparatif. Populasi dalam penelitian ini adalah seluruh petani cabai rawit lokal dan hibrida di Desa Gambangan yang berjumlah 233 orang. Sampel diambil menggunakan cluster random sampling berjumlah 70 orang. Data yang di ambil menggunakan teknik wawancara dan dokumentasi serta dianalisis dengan analisis uji Independent sample t-test. Hasil penelitian ini menunjukkan bahwa tingkat keuntungan petani cabai rawit lokal dengan luas lahan lebih dari $5000 \mathrm{~m}^{2}$ yaitu sebesar Rp.104.491.148, serta luas lahan kurang dari $5000 \mathrm{~m}^{2}$ yaitu sebesar Rp.45.917.770, tingkat keuntungan petani cabai rawit hibrida dengan luas lahan lebih dari $5000 \mathrm{~m}^{2}$ yaitu sebesar Rp.107.443.650, serta luas lahan kurang dari $5000 \mathrm{~m}^{2}$ yaitu sebesar Rp.63.994.614, dan terdapat perbedaan yang signifikan tingkat keuntungan cabai rawit lokal dan cabai rawit hibrida dengan luas lahan lebih dari $5000 \mathrm{~m}^{2}$ yang ditunjukkan dari nilai t 2.464 dengan nilai sig $0.049<0.05$, serta luas lahan kurang dari $5000 \mathrm{~m}^{2}$ yang ditunjukkan dari nilai t 2.419 dengan nilai sig 0.024 $<0.05$.
\end{abstract}

Kata kunci: Tingkat Keuntungan, Profitabilitas, Usahatani.

\begin{abstract}
This study aims to test the total level of profit local chili pepper for farming hybrid chili pepper, and the difference of profit level local chili pepper and hybrid chili pepper for farmers. This type of research is a comparative descriptive research. The population in this study were all local and hybrid chili pepper farmers in Gambangan Village which amoutnts 233 people. The sample was taken using cluster random sampling amounting to 70 people. Data taken using interview technique and analyzed by analysis of test Independent sample t-test. The results of this study indicate that the level of profit of local chili peper farmers with a land area of more than $5000 \mathrm{~m}^{2}$ of Rp. 104,491,148, and the land area is less than $5000 \mathrm{~m}^{2}$ which is Rp.45.917.770, Profit rate of hybrid chili pepper farmer with land area more than $5000 \mathrm{~m}^{2}$ that is Rp.107,443,650, and the land area is less than $5000 \mathrm{~m}^{2}$ which is Rp.63.994.614, and there is a significant difference in the profitability level of local chili and hybrid pepper with a land area of more than $5000 \mathrm{~m}^{2}$ indicated from the value of $t 2.464$ as well as the sig value $0.049<0.05$, and the land area is less than $5000 \mathrm{~m}^{2}$ indicated from the value of $t 2.419$ as well as the sig value $0.024<0.05$.
\end{abstract}

Keywords: Profit, Level Profitability, Farming. 


\section{PENDAHULUAN}

Pertanian dalam pengertian yang luas adalah kegiatan pemanfaatan lahan, tanaman, hewan dan mikrobia untuk kepentingan manusia. Pertanian menjadi salah satu sektor primer yang menyokong perekonomian Indonesia, (Fauzi, 2008), namun dalam pengelolaan usaha tani banyak ditemukan kendala seperti keterbatasan pengetahuan petani dalam mengelola usahataninya, keterbatasan lahan yang dimiliki petani dan keterbatasan teknologi yang digunakan petani dalam mengelola usahataninya, hal tersebut menyebabkan rendahnya keuntungan yang diperoleh petani.

Menurut Shinta (2011:1) "usaha tani adalah usaha menggunakan sumberdaya secara efektif dan efisien pada suatu usaha pertanian agar diperoleh hasil maksimal, sumber daya yang dimaksud adalah lahan, tenaga kerja, modal dan manajemen" selaras dengan pendapat tersebut, Soetriono dkk (2006:27) berpendapat bahwa usaha tani merupakan proses menentukan dan mengkoordinasikan penggunaan faktorfaktor produksi pertanian untuk memperoleh keuntungan yang maksimal. Hal ini sesuai dengan apa yang dikemukakan oleh Daniel (2004:67) "usaha tani adalah suatu kegiatan yang mengorganisasikan sarana produksi pertanian dan teknologi dalam suatu usaha yang menyangkut bidang pertanian dengan tujuan memperoleh keuntungan. Berdasarkan beberapa pengertian usaha tani tersebut, maka dapat disimpulkan bahwa yang dimaksud dengan usaha tani adalah usaha pemanfaatkan lahan, tenaga kerja, modal dan teknologi yang dilakukan oleh petani dengan tujuan memperoleh keuntungan (profitabilitas) secara maksimal.

Profitabilitas merupakan gambaran kemampuan suatu usaha untuk mendapatkan keuntungan bersih dari modal operasional yang dikeluarkan atau operasional biaya/biaya produksi (Soekartawi, 2005). Menurut Hernanto (2011:88) "keuntungan usaha tani adalah selisih antara penerimaan (total revenue) dan semua biaya yang dikeluarkan (total cost) oleh petani”. Hal senada juga dikemukakan oleh Gustiyana (2004) bahwa keuntungan (profitabilitas) usaha tani dapat diukur melalui selisih antara penerimaan dengan biaya total atau biaya yang secara aktual dikeluarkan oleh petani. Dalam ilmu ekonomi pertanian juga dikatakan bahwa keuntungan usaha tani dapat dihitung dengan membandingkan antara hasil yang diharapkan akan diterima pada waktu panen (total revenue) dengan biaya (total cost) yang harus dikeluarkan.

Untuk mengetauhi tingkat keuntungan dalam usaha tani yaitu dengan cara menghitung selisih pendapatan dengan biaya produksi yang dikeluarkan. Pendapatan usaha tani merupakan hasil penjualan atau pertukaran hasil produksi yang dinilai dalam rupiah berdasarkan harga per satuan berat pada saat panen Siregar (2011:22), Hal ini sesuai dengan pernyataan yang dikemukakan oleh Ahmadi (2005) bahwa pendapatan usaha tani merupakan hasil perkalian jumlah produk total dengan satuan harga jual.

Hansen \& Mowen (2004) mengemukakan bahwa biaya produksi merupakan biaya yang berkaitan dengan pembuatan barang dan penyediaan jasa. Menurut Soekartawi (2005) biaya produksi dalam usaha tani merupakan semua pengeluaran yang digunakan dalam usaha tani baik biaya tetap maupun biaya tidak tetap. Biaya tetap adalah biaya yang besarnya tidak tergantung pada besar kecilnya produksi yang akan dihasilkan sedangkan biaya tidak tetap adalah biaya yang besar kecilnya dipengaruhi oleh volume produksi.

Pada saat ini para petani dihadapkan pada alternatif pilihan tanaman salah satunya yaitu cabai, tanaman cabai dengan berbagai macam varietas, diantaranya varietas cabai rawit hibrida dan cabai rawit lokal. Kedua jenis cabai ini memiliki banyak perbedaan jika dilihat dari teknik produksi, harga pasar, dan biaya faktor produksi (benih, pupuk dan pestisida). Dari kedua jenis cabai rawit tersebut jika dilihat dari keuntungannya (profitabilitas) para petani memerlukan perhitungan secara ekonomis untuk memperoleh hasil kerja yang optimal. 
Di Desa Gambangan hampir semua penduduknya berprofesi sebagai petani. Desa ini memiliki potensi lahan perkebunan untuk sayuran 90.57 ha, suhu rata-rata $26 \stackrel{\circ}{\circ}$, ketinggian $350 \mathrm{M}$ dibawah permukaan laut, dengan tekstur tanah jenis tanah persawahan, dan masyarakat yang bertani 708 orang (Rancanagan Kerja Pemerintah Desa Gambangan Tahun 2017), dengan potensi yang dimiliki desa ini maka petani perlu berupaya untuk memanfaatkan lahannya seoptimal mungkin dengan tanaman yang cocok dan memiliki potensi pasar yang luas sehingga bisa memberikan manfaat atau keuntungan yang maksimal bagi petani. Namun di desa ini terdapat fenomena yang menunjukkan bahwa petani lebih banyak memproduksi dua jenis cabai rawit yaitu cabai rawit lokal dan cabai rawit hibrida. Masing-masing jenis cabai rawit tersebut tentunya memiliki keunggulan dan kelemahan yang berbeda yang akan menjadi harapan bagi petani untuk memperoleh keuntungan maksimal. Pemilihan jenis cabai rawit lokal dan cabai rawit hibrida di desa ini berdasarkan pada keputusan petani untuk memaksimalkan tingkat keuntungan (profitabilitas) dari usahataninya.

Berdasarkan survey pendahuluan peneliti yang diperoleh dari Gapoktan Desa Gambangan pada tahun 2017 di desa tersebut $69,52 \%$ petani menanam jenis cabai rawit hibrida dan $23,06 \%$ petani menanam jenis cabai rawit lokal, serta $7,42 \%$ petani menanam jenis cabai lainnya. Dapat disimpulkan bahwa tanaman cabai rawit hibrida dan cabai rawit lokal merupakan dua jenis cabai yang menguntungkan bagi petani di Desa Gambangan dilihat dari banyaknya petani yang menanam jenis cabai rawit tersebut.

Untuk mengetahui perbedaan tingkat keuntungan dari kedua jenis cabai rawit tersebut, maka perlu dikaji tentang perbandingan tingkat keuntungan (profitabilitas) petani dalam memproduksi jenis cabai rawit lokal maupun hibrida hibrida.

\section{METODE PENELITIAN}

Jenis penelitian ini merupakan penelitian deskriptif komparatif. Populasi dalam penelitian ini adalah seluruh petani cabai rawit lokal dan hibrida di Desa Gambangan yang berjumlah 233 orang. Dari jumlah populasi yang cukup banyak maka hanya sebagian diambil untuk dijadikan sampel, untuk menentukan jumlah sampel dari sautu populasi digunakan rumus slovin sebagai berikut.

$n=\frac{N}{1+N \cdot e^{2}}$

$n=\frac{233}{1+233 \cdot(10 \%)^{2}}$

$n=69,96$

Keterangan:

$\mathrm{n}=$ Ukuran sampel

$\mathrm{N}=$ Ukuran populasi (233)

$\mathrm{e}=$ Persen kelonggaran ketidaktelitian karena kesalahan pengambilan sampel yang masih dapat ditolerir atau diinginkan, sebanyak $10 \%$.

Hasil yang diperoleh dari rumus tersebut yaitu sebanyak 69,96 dan dibulatkan menjadi sebanyak 70 sampel.

Berdasarkan rumus tersebut maka jumlah sampel yang diambil dalam penelitian ini sebesar 70 responden. Penarikan sampel dalam penelitian ini menggunakan Cluster Random Sampling yaitu pengambilan sampel dari populasi yang dianggap heterogen menurut karakteristik tertentu dikelompokkan kedalam sub-populasi secara kluster sehingga unsur-unsurnya menjadi heterogen, dari 70 sampel yang terdiri dari petani cabai rawit lokal dan hibrida dibagi menjadi dua kelompok berdasarkan varietas cabai rawit yang dibudidayakan, selanjutnya masingmasing kelompok dibagi kembali menjadi dua kelompok berdasarkan luas lahan pertanian yang dimiliki. Pengumpulan data dilakukan dengan metode wawancara serta dianalisis dengan analisis uji Independent sample t-test, pengujian hipotesis dilakukan dengan menggunakan Statistical Program Social Scence (SPSS) 16.0 for windows. Sumber data yang digunakan dalam penelitian ini adalah data primer, data yang diperoleh penulis langsung dari responden petani cabai dalam bentuk wawancara serta tanggapan tertulis responden terhadap sejumlah pertanyaan yang diajukan dalam wawancara penelitian data yang diperoleh secara langsung terkait dengan tingkat 
keuntungan profitabilitas usahatani cabai rawit lokal dan hiibrida. Wawancara merupakan bentuk komunikasi verbal semacam percakapan yang bertujuan memperoleh informasi. Wawancara merupakan metode pengumpulan data dengan cara tanya jawab yang dikerjakan dengan sistematis

\section{HASIL DAN PEMBAHASAN}

Tingkat Keuntungan Jenis Cabai Rawit Lokal bagi Usahatani Di Desa Gambangan Kecamatan Maesan Kabupaten Bondowoso Jawa Timur 2017
Profitabilitas (tingkat keuntungan) jenis cabai rawit lokal bagi usahatani di Desa Gambangan Kecamatan Maesan Kabupaten Bondowoso Jawa Timur tahun 2017 dapat diketahui tingkat keuntungannya dengan menghitung seluruh biaya-biaya yang dikeluarkan oleh petani dan pendapatan yang di peroleh petani. Hasil penelitian yang diperoleh untuk tingkat keuntungan (profitabilitas) dari jenis cabai rawit lokal dengan luas lahan lebih dari 5000 meter persegi dapat dilihat pada tabel 1.

Tabel 1. Rata-rata Tingkat Keuntungan Jenis Cabai Rawit Lokal bagi Usahatani dengan luas lahan lebih dari 5000 meter persegi $\left(>5000 \mathrm{~m}^{2}\right)$

\begin{tabular}{|c|c|c|c|}
\hline \multirow{2}{*}{$\frac{\mathrm{N}}{1}$} & Uraian & Perhitungan (Rp) & Jumlah (Rp) \\
\hline & Jumlah Produksi $/ \mathrm{Kg}(\mathrm{Y})$ & 8.400 & \\
\hline \multirow{2}{*}{$\begin{array}{l}1 . \\
2 .\end{array}$} & Harga Produksi & 16.000 & \\
\hline & Total Penerimaan (TR) Y x Py & & 134.400 .000 \\
\hline \multirow[t]{4}{*}{3.} & Biaya Tetap (FC) & & \\
\hline & a. Biaya pajak & 33.852 & \\
\hline & b. Biaya pengolahan lahan & 1.700 .000 & \\
\hline & $\begin{array}{l}\text { c. Biaya penyusutan alat } \\
\text { d. Biava irigasi }\end{array}$ & $\begin{array}{l}1.650 .000 \\
280.000\end{array}$ & \\
\hline
\end{tabular}

Total Biaya Tetap (TFC)

4. Biaya Variabel (VC)
a. Biaya pembibitan
b. Biaya pupuk
c. Biaya pestisida
d. Biaya tenaga kerja
4.400 .000
760.000
85.000
21.000 .000

Total Biaya Variabel (TVC)

Total Biaya Produksi (TC)

26.245 .000

3.663.852

5. Keuntungan (profitabilitas)

Berdasarkan data yang diperoleh pada Tabel 1 mengenai perhitungan usahatani cabai rawit lokal di Desa Gambangan Kecamatan Maesan Kabupaten Bondowoso Jawa Timur tahun 2017 dalam satu musim tanam, diketahui bahwa biaya-biaya yang dikeluarkan oleh petani yaitu terdapat total biaya tetap sebesar Rp.3.663.852 dan total biaya variable sebesar Rp.26.245.000, sehingga dapat diketahui seluruh biaya yang dikeluarka total biaya produksi sebesar Rp.29.908.852. Hasil produksi cabai rawit lokal dalam satu musim tanam yaitu 8.400 $\mathrm{kg}$ dengan harga jual per $\mathrm{kg}$ sebesar Rp.16.000, sehingga diperoleh jumlah total penerimaan oleh petani sebesar Rp.134.400.000. Keuntungan petani cabai

rawit lokal dalam satu musim tanam yaitu sebesar Rp. 104.491.148, yang diperoleh dari selisih antara total penerimaan petani dengan total biaya yang dikeluarkan oleh petani. Jadi tingkat keuntungan dari jenis cabai rawit lokal dengan luas lahan lebih dari $5000 \mathrm{~m}^{2}$ di Desa Gambangan Kecamatan Maesan Kabupaten Bondowoso Jawa Timur tahun 2017 adalah sebesar Rp.104.491.148. Hasil analisis rasio atas penerimaan biaya $(R / C)$ untuk cabai rawit lokal dengan luas lahan $>5000 \mathrm{~m}^{2}$ nilai $\mathrm{R} / \mathrm{C}$ atas biaya total yaitu sebesar 3.50, maka dapat dikatakan bahwa usahatani cabai rawit lokal dengan luas lahan $>5000 \mathrm{~m}^{2}$ menguntungkan dan efisien untuk diusahakan,karena nilai $\mathrm{R} / \mathrm{C}$ lebih besar dari $1 \quad(\mathrm{R} / \mathrm{C}>1)$ 
Tingkat Keuntungan Jenis Cabai Rawit Lokal bagi Usahatani dengan luas lahan kurang dari 5000 meter persegi $\left(<5000 \mathrm{~m}^{2}\right)$.

Profitabilitas (tingkat keuntungan) jenis cabai rawit lokal bagi usahatani di Desa Gambangan Kecamatan Maesan Kabupaten Bondowoso Jawa Timur tahun 2017 dapat diketahui tingkat keuntungannya dengan menghitung seluruh biaya-biaya yang dikeluarkan oleh petani dan pendapatan yang di peroleh petani. Hasil penelitian yang diperoleh untuk tingkat keuntungan (profitabilitas) dari jenis cabai rawit lokal dengan luas lahan kurang dari 5000 meter persegi dapat dilihat pada tabel 2 .

Tabel 2. Rata-rata Tingkat Keuntungan Jenis Cabai Rawit Lokal dengan luas lahan kurang dari 5000 meter persegi $\left(<5000 \mathrm{~m}^{2}\right)$.

\begin{tabular}{cll}
\hline No & \multicolumn{1}{c}{ Uraian } & \multicolumn{1}{c}{ Perhian } \\
\hline 1. & Jumlah Produksi $/ \mathrm{Kg}(\mathrm{Y})$ & 3.600 \\
2. & Harga Produksi & 16.000 \\
& Total Penerimaan (TR) Y x Py & \\
3. & Biaya Tetap (FC) & \\
& a. Biaya pajak & 18.230 \\
& b. Biaya pengolahan lahan & 600.000 \\
& c. Biaya penyusutan alat & 550.000 \\
& d. Biaya irigasi & 120.000
\end{tabular}

4. Biaya Variabel (VC)
a. Biaya pembibitan
900.000
b. Biaya pupuk
324.000
c. Biaya pestisida
170.000
d. Biaya tenaga kerja
9.000 .000

Total Biaya Variabel (TVC)

Total Biaya Produksi (TC)

1.288 .230 Jumlah (Rp)

57.600 .000

5. Keuntungan (profitabilitas) 10.394 .000

(11.682.230)

45.917.770

Berdasarkan data yang diperoleh pada Tabel 2 mengenai perhitungan usahatani cabai rawit lokal di Desa Gambangan Kecamatan Maesan Kabupaten Bondowoso Jawa Timur tahun 2017 dalam satu musim tanam, diketahui bahwa biaya-biaya yang dikeluarkan oleh petani yaitu terdapat total biaya tetap sebesar Rp.1.288.230 dan total biaya variabel sebesar Rp.10.394.000, sehingga dapat diketahui seluruh biaya yang dikeluarka total biaya produksi sebesar Rp.11.682.230. Hasil produksi cabai rawit lokal dalam satu musim tanam yaitu 3.600 $\mathrm{kg}$ dengan harga jual per $\mathrm{kg}$ sebesar Rp.16.000, sehingga diperoleh jumlah total penerimaan oleh petani sebesar Rp. 57.600.000. Keuntungan petani cabai rawit lokal dalam satu musim tanam yaitu sebesar Rp.45.917.770, yang diperoleh dari selisih antara total penerimaan petani dengan total biaya yang dikeluarkan oleh

petani. Jadi tingkat keuntungan dari jenis cabai rawit lokal dengan luas lahan kurang dari $5000 \mathrm{~m}^{2}$ di Desa Gambangan Kecamatan Maesan Kabupaten Bondowoso Jawa Timur tahun 2017 adalah sebesar Rp.45.917.770. Hasil analisis rasio penerimaan atas biaya $(R / C)$ untuk cabai rawit lokal dengan luas lahan $<5000 \mathrm{~m}^{2}$ nilai $\mathrm{R} / \mathrm{C}$ atas biaya total yaitu sebesar 3.94, maka dapat dikatakan bahwa usahatani cabai rawit lokal dengan luas lahan $<5000 \mathrm{~m}^{2}$ menguntungkan dan efisien untuk diusahakan,karena nilai $\mathrm{R} / \mathrm{C}$ lebih besar dari $1(\mathrm{R} / \mathrm{C}>1)$.

Tingkat Keuntungan Jenis Cabai Rawit Hibrida dengan luas lahan lebih dari 5000 meter persegi $\left(>5000 \mathrm{~m}^{2}\right)$

Profitabilitas (tingkat keuntungan) jenis cabai rawit hibrida bagi usahatani di Desa Gambangan Kecamatan Maesan Kabupaten Bondowoso Jawa Timur tahun 
2017 dapat diketahui tingkat keuntungannya dengan menghitung seluruh biaya-biaya yang dikeluarkan oleh petani dan pendapatan yang di peroleh oleh petani. Hasil penelitian yang diperoleh untuk tingkat keuntungan (profitabilitas) dari jenis cabai rawit hibridal dengan luas lahan lebih dari 5000 meter persegi dapat dilihat pada tabel 3 .

Tabel 3. Rata-rata Tingkat Keuntungan Jenis Cabai Rawit Hibrida dengan luas lahan lebih dari 5000 meter persegi $\left(>5000 \mathrm{~m}^{2}\right)$.

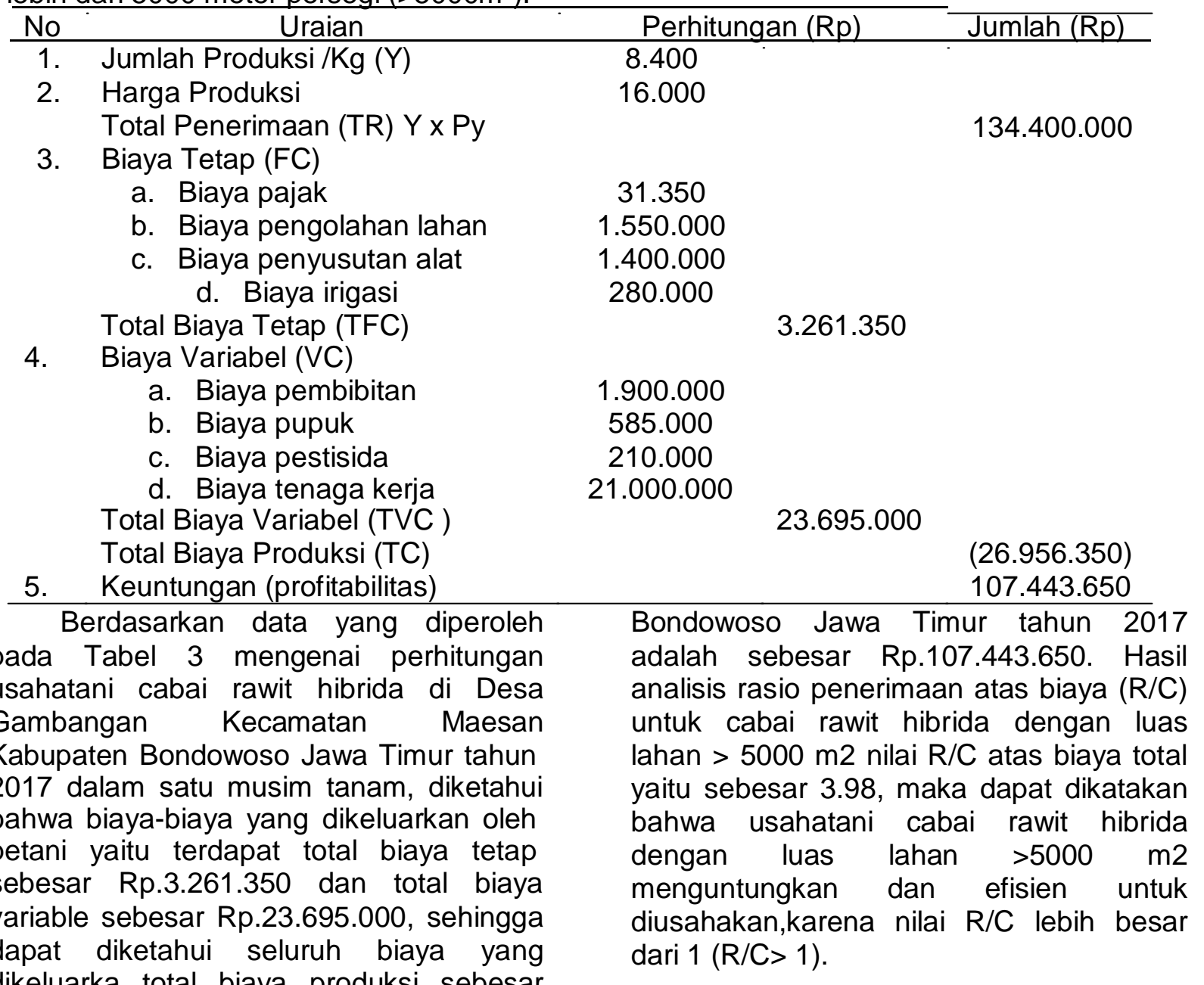

dikeluarka total biaya produksi sebesar Rp. 26.956.350. Hasil produksi cabai rawit hibrida dalam satu musim tanam yaitu $8.400 \mathrm{~kg}$ dengan harga jual per $\mathrm{kg}$ sebesar Rp.16.000, sehingga diperoleh jumlah total penerimaan oleh petani sebesar Rp.134.400.000. Keuntungan petani cabai rawit hibrida dalam satu musim tanam yaitu sebesar Rp.107.443.650, yang diperoleh dari selisih antara total penerimaan petani dengan total biaya yang dikeluarkan oleh petani. Jadi tingkat keuntungan dari jenis cabai rawit hibrida dengan luas lahan lebih dari $5000 \mathrm{~m}^{2}$ di Desa Gambangan Kecamatan Maesan Kabupaten

Tingkat Keuntungan Jenis Cabai Rawit Hibrida dengan luas lahan kurang dari 5000 meter persegi $\left(<5000 \mathrm{~m}^{2}\right)$.

Profitabilitas (tingkat keuntungan) jenis cabai rawit hibrida bagi usahatani di Desa Gambangan Kecamatan Maesan Kabupaten Bondowoso Jawa Timur tahun 2017 dapat diketahui tingkat keuntungannya dengan menghitung seluruh biaya-biaya yang dikeluarkan oleh petani dan pendapatan yang di peroleh petani. Dalam ilmu ekonomi pertanian juga dikatakan bahwa keuntungan usaha tani dapat dihitung dengan membandingkan antara hasil yang diharapkan akan 
diterima pada waktu panen (total revenue) dengan biaya (total cost) yang harus dikeluarkan. Hasil penelitian yang diperoleh untuk tingkat keuntungan (profitabilitas) dari jenis cabai rawit lokal dengan luas lahan kurang dari 5000 meter persegi dapat dilihat pada tabel 4.

Tabel 4. Rata-rata Tingkat Keuntungan Jenis Cabai Rawit Hibrida dengan luas lahan kurang dari 5000 meter persegi $\left(<5000 \mathrm{~m}^{2}\right)$.

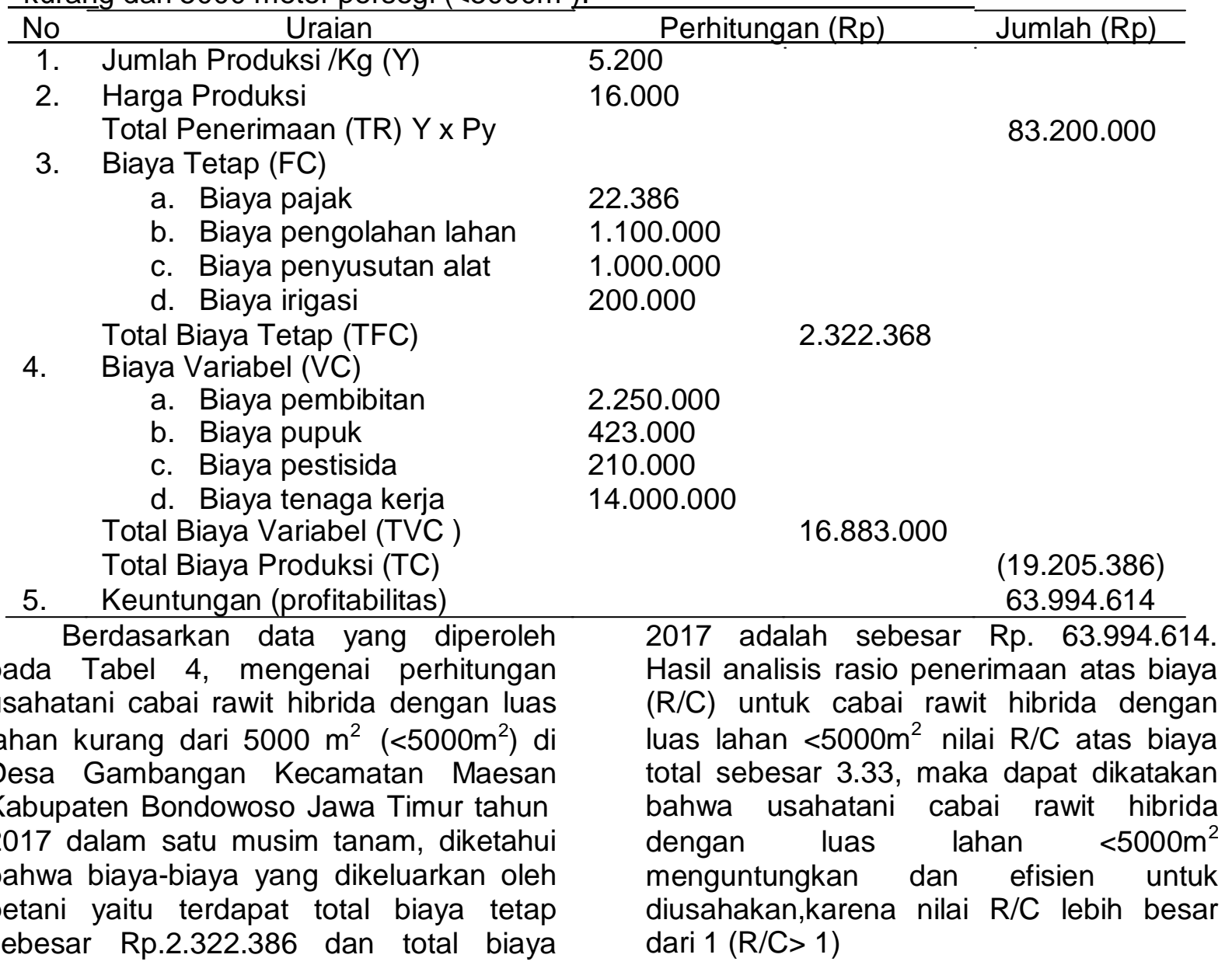

variabel sebesar Rp.16.883.000, sehingga dapat diketahui seluruh biaya yang dikeluarka total biaya produksi sebesar Rp. 19.205.386. Hasil produksi cabai rawit lokal dalam satu musim tanam yaitu 5.200 $\mathrm{kg}$ dengan harga jual per $\mathrm{kg}$ sebesar Rp.16.000, sehingga diperoleh jumlah total penerimaan oleh petani sebesar Rp.83.200.000. Keuntungan petani cabai rawit hibrida dalam satu musim tanam yaitu sebesar Rp.63.994.614, yang diperoleh dari selisih antara total penerimaan petani dengan total biaya yang dikeluarkan oleh petani. Jadi tingkat keuntungan dari jenis cabai rawit hibrida dengan luas lahan kurang dari $5000 \mathrm{~m}^{2}$ di Desa Gambangan Kecamatan Maesan Kabupaten Bondowoso Jawa Timur tahun

Perbedaan tingkat keuntungan antara jenis cabai rawit lokal dan cabai rawit hibrida dengan luas lahan lebih dari $5000 \mathrm{~m}^{2}\left(>5000 \mathrm{~m}^{2}\right)$.

Profitabilitas usahatani cabai rawit lokal dan cabai rawit hibrida pada petani di Desa Gambangan Kecamatan Maesan Kabupaten Bondowoso dapat diketahui perbedaan tingkat keuntungan (profitabilitas) dengan menggunakan uji Independent Sample T-test. Tingkat perbedaan profitabilitas pada usahatani cabai rawit lokal dan cabai rawit hibrida terdapat luas lahan yag berbeda yaitu luas lahan lebih dari $5000 \mathrm{~m}^{2}$ dan kurang dari $500 \mathrm{~m}^{2}$ 
Tabel 5 Group Statistic Tingkat Perbedaan Profitabilitas Usahatani Cabai Rawit Lokal dan Cabai Rawit Hibrida dengan luas lahan lebih dari 5000 meter persegi $\left(>5000 \mathrm{~m}^{2}\right)$.

\begin{tabular}{|c|c|c|c|c|c|}
\hline \multicolumn{6}{|c|}{ Group Statistics } \\
\hline & Profitabilitas & $\mathrm{N}$ & Mean (Rp) & $\begin{array}{c}\text { Std. } \\
\text { Deviation }\end{array}$ & $\begin{array}{l}\text { Std. Error } \\
\text { Mean }\end{array}$ \\
\hline Varietas & $\begin{array}{l}\text { Cabai Rawit Lokal Luas } \\
\text { Lahan }>5000 \mathrm{~m} 2\end{array}$ & 18 & 104.256.202. & 1.89237 & 4458426.145 \\
\hline Cabai & $\begin{array}{l}\text { Cabai Rawit Hibrida Luas } \\
\text { Lahan }>5000 \mathrm{~m} 2\end{array}$ & 18 & 107.508 .171 & 2.69567 & 6351787.528 \\
\hline
\end{tabular}

Dari Tabel 5 dapat dilihat bahwa ratarata profitabilitas usahatani cabai rawit lokal dan hibrida dengan lus lahan lebih dari 5000m2 petani di Desa Gambangan Kecamatan maesan Kabupaten Bondowoso Jawa Timur tahun 2017. Hasil rata-rata tingkat keuntungan (Profitabilitas) cabai rawit lokal dengan luas lahan $>5000 \mathrm{~m}^{2}$ sebesar 104.256.202 dan hasi rata-rata tingkat keuntungan(Profitabilitas) cabai rawit hibrida sebesar 107.508.171. Jadi dapat disimpulkan bahwa tingkat keuntungan (Profitabilitas) cabai rawit lokal lebih kecil dari keuntungan (Profitabilitas) cabai rawit hibrida dengan luas lahan yang sama yaitu luas lebih dari $5000 \mathrm{~m}^{2}\left(>5000 \mathrm{~m}^{2}\right)$.
Dari ke dua jenis cabai rawit lokal maupun hibrida sama-sama menguntungkan bagi petani cabai, namun tingkat keuntungannya lebih besar jenis cabai rawit hibrida dilihat dengan luas lahan lebih dari $5000 \mathrm{~m}^{2} \quad\left(>5000 \mathrm{~m}^{2}\right)$.Untuk menguji signifikan perbedaan digunakan analisis uji hipotesis yaitu analisis yang dimaksudkan untuk menguji hipotesis yang diajukan dalam penelitian ini, sehingga hipotesis tersebut dapat diterima kebenarannya atau ditolak kebenarannya. Berdasarkan analisis uji Independent Sample T-Test dengan bantuan program SPSS 16.00 for windows dapat dilihat pada

Tabel

Tabel 6. Profitabilitas Usahatani Cabai Rawit Lokal dan Cabai Rawit Hibrida dengan luas lahan lebih dari 5000 meter persegi $\left(>5000 \mathrm{~m}^{2}\right)$.

\begin{tabular}{llllll}
\hline Variabel & $\begin{array}{l}\text { Sig. } \\
\text { tailed })\end{array}$ & $\left(2-\frac{1}{t_{\text {hitung }}}\right.$ & $t_{\text {tabel }}$ & Keputusan & Arti \\
\hline Profitabilitas & 0.049 & 2.464 & 2.030 & $\begin{array}{l}\text { Ha diterima dan } \\
\text { Ho ditolak }\end{array}$ & $\begin{array}{l}\text { Ada perbedaan } \\
\text { yang signifikan }\end{array}$
\end{tabular}

Dari Tabel 6, berdasarkan hasil analisis uji Independent Sample T-Test dengan menggunakan bantuan SPSS 16.00 for windows, diperoleh nilai $t_{\text {hitung }}$ sebesar

2.464 sedangkan $t_{\text {tabel }}$ sebesar 2.030 . Dengan demikian nilai $t_{\text {hitung }}$ dibandingakan dengan $t_{\text {tabel }}$ pada taraf signifikan $5 \%$ ternyata nilai $t_{\text {hitung }}$ lebih besar dari nilai $t_{\text {tabel, }}$ maka $\mathrm{Ha}$ diterima dan Ho ditolak, berarti ada perbedaan yang signifikan anatara tingkat keuntungan (Profitabilitas) usahatani cabai rawit lokal dan cabai rawit hibrida dengan luas lahan lebih dari $5000 \mathrm{~m}^{2}\left(>5000 \mathrm{~m}^{2}\right)$ bagi petani di Desa Gambangan Kecamatan Maesan Kabupaten Bondowoso Jawa Timur tahun 2017.

Perbedaan Tingkat Keuntungan Jenis Cabai Rawit Lokal dan Cabai Rawit Hibrida dengan Luas Lahan Kurang dari $5000 \mathrm{~m}^{2}$.

keuntungan (Profitabilitas) usahatani cabai rawit lokal dan cabai rawit hibrida dengan luas lahan lebih dari $5000 \mathrm{~m}^{2}\left(>5000 \mathrm{~m}^{2}\right)$ 
$\begin{array}{llll}\text { bagi petani } & \text { di Desa } & \text { Gambangan } & \text { Bondowoso Jawa Timur } 2017 \\ \text { Kecamatan } & \text { Maesan } & \text { Kabupaten } & \end{array}$

Tabel 7 Group Statistic Tingkat Perbedaan Profitabilitas Usahatani Cabai Rawit Lokal dan Cabai Rawit Hibrida dengan luas lahan kurang dari 5000 meter persegi $\left(<5000 \mathrm{~m}^{2}\right)$.

\begin{tabular}{|c|c|c|c|c|c|}
\hline \multicolumn{6}{|c|}{ Group Statistics } \\
\hline & Profitabilitas & $\mathrm{N}$ & Mean (Rp) & $\begin{array}{c}\text { Std. } \\
\text { Deviation }\end{array}$ & $\begin{array}{l}\text { Std. Error } \\
\text { Mean }\end{array}$ \\
\hline Varietas & $\begin{array}{l}\text { Cabai Rawit Lokal Luas } \\
\text { Lahan }<5000 \mathrm{~m} 2\end{array}$ & 17 & 44.421.374 & 1.56017 & 3784355.917 \\
\hline Cabai & $\begin{array}{l}\text { Cabai Rawit Hibrida Luas } \\
\text { Lahan }<5000 \mathrm{~m} 2\end{array}$ & 17 & 61.361 .855 & 2.36677 & 5738856.695 \\
\hline
\end{tabular}

Dari Tabel 7, dapat dilihat bahwa ratarata profitabilitas usahatani cabai rawit lokal dan hibrida dengan lus lahan kurang dari $5000 \mathrm{~m}^{2}$ petani di Desa Gambangan Kecamatan maesan Kabupaten Bondowoso Jawa Timur tahun 2017. Hasil rata-rata tingkat keuntungan (Profitabilitas) cabai rawit lokal dengan luas lahan $<5000 \mathrm{~m}^{2}$ sebesar 44.421 .374 dan hasi rata-rata tingkat keuntungan(Profitabilitas) cabai rawit hibrida sebesar 61.361.855. Jadi dapat disimpulkan bahwa tingkat keuntungan (Profitabilitas) cabai rawit lokal lebih kecil dari keuntungan (Profitabilitas) cabai rawit hibrida dengan luas lahan yang sama yaitu luas kurang dari $5000 \mathrm{~m}^{2}\left(<5000 \mathrm{~m}^{2}\right)$.
Dari ke dua jenis cabai rawit lokal maupun hibrida sama-sama menguntungkan bagi petani cabai, namun tingkat keuntungannya lebih besar jenis cabai rawit hibrida dilihat dengan luas lahan kurang dari $5000 \mathrm{~m}^{2}\left(<5000 \mathrm{~m}^{2}\right)$.

Untuk menguji signifikan perbedaan digunakan analisis uji hipotesis yaitu analisis yang dimaksudkan untuk menguji hipotesis yang diajukan dalam penelitian ini, sehingga hipotesis tersebut dapat diterima kebenarannya atau ditolak kebenarannya. Berdasarkan analisis uji Independent Sample T-Test dengan bantuan program SPSS 16.00 for windows dipat dilihat pada Tabel 8.

Tabel 8. Profitabilitas Usahatani Cabai Rawit Lokal dan Cabai Rawit Hibrida di dengan luas lahan kurang dari 5000 meter persegi $\left(<5000 \mathrm{~m}^{2}\right)$.

\begin{tabular}{ccccccc}
\hline Variabel & $\begin{array}{c}\text { Sig. (2- } \\
\text { tailed) }\end{array}$ & $t_{\text {hitung }}$ & $t_{\text {tabel }}$ & Keputusan & Arti \\
\hline Profitabilitas & 0.024 & 2.419 & 2.030 & $\begin{array}{l}\text { Ha diterima dan } \\
\text { Ho ditolak }\end{array}$ & $\begin{array}{l}\text { Ada perbedaan } \\
\text { yang signifikan }\end{array}$
\end{tabular}

Dari Tabel 8, berdasarkan hasil analisis uji Independent Sample T-Test dengan menggunakan bantuan SPSS 16.00 for windows, diperoleh nilai $t_{\text {hitung }}$ sebesar

2.419 sedangkan $t_{\text {tabel }}$ sebesar 2.030 Dengan demikian nilai $t_{\text {hitung }}$ dibandingakan dengan $t_{\text {tabel }}$ pada taraf signifikan $5 \%$ ternyata nilai $t_{\text {hitung }}$ lebih besar dari nilai $t_{\text {tabel }}$, maka $\mathrm{Ha}$ diterima dan Ho ditolak, berarti ada perbedaan yang signifikan anatara tingkat keuntungan (Profitabilitas) usahatani cabai rawit lokal dan cabai rawit hibrida dengan luas lahan kurang dari $5000 \mathrm{~m}^{2}\left(<5000 \mathrm{~m}^{2}\right)$ bagi petani di Desa Gambangan Kecamatan Maesan Kabupaten Bondowoso Jawa Timur tahun 2017.

\section{Pembahasan}


Berdasarkan hasil penelitian yang telah dilakukan mengenai perhitungan usahatani cabai rawit lokal di Desa Gambangan Kecamatan Maesan Kabupaten Bondowoso Jawa Timur tahun 2017 dalam satu musim tanam, diketahui bahwa rata-rata tingkat keuntungan petani cabai rawit lokal dalam satu musim tanam dengan luas lahan lebih dari $5000 \mathrm{~m}^{2}$ (> $5000 \mathrm{~m}^{2}$ ) yaitu sebesar Rp. 104.491.148, sedangkan tingkat keuntungan dari jenis cabai rawit lokal dengan luas lahan kurang dari $5000 \mathrm{~m}^{2}\left(<5000 \mathrm{~m}^{2}\right)$ yaitu sebesar Rp. 45.917.770. Hasil tesebut diperoleh dari selisih antara total penerimaan petani dengan total biaya yang dikeluarkan oleh petani. Hasil analisis R/C untuk cabai rawit lokal dengan luas lahan $>5000 \mathrm{~m}^{2}$ nilai $\mathrm{R} / \mathrm{C}$ atas biaya total 3.50 dan nilai $\mathrm{R} / \mathrm{C}$ atas biaya tunai sebesar 3.49 maka dapat dikatakan bahwa usahatani cabai rawit lokal dengan luas lahan $>5000 \mathrm{~m}^{2}$ menguntungkan dan efisien untuk diusahakan,karena nilai $\mathrm{R} / \mathrm{C}$ lebih besar dari $1(R / C>1)$. Sedangkan hasil analisis $\mathrm{R} / \mathrm{C}$ untuk cabai rawit lokal dengan luas lahan $<5000 \mathrm{~m}^{2}$ nilai $\mathrm{R} / \mathrm{C}$ atas biaya total 3.94 dan nilai $\mathrm{R} / \mathrm{C}$ atas biaya tunai sebesar 3.93 maka dapat dikatakan bahwa usahatani cabai rawit lokal dengan luas lahan $<5000 \mathrm{~m}^{2}$ menguntungkan dan efisien untuk diusahakan,karena nilai $\mathrm{R} / \mathrm{C}$ lebih besar dari $1(\mathrm{R} / \mathrm{C}>1)$.

Adapun hasil penelitian yang telah dilakukan mengenai perhitungan usahatani cabai rawit hibrida diketahui bahwa tingkat keuntungan petani cabai rawit hibrida dalam satu musim tanam dengan luas lahan lebih dari $5000 \mathrm{~m}^{2}$ $\left(>5000 \mathrm{~m}^{2}\right)$ yaitu sebesar Rp.107.443.650,

Sedangkan tingkat keuntungan dari jenis cabai rawit hibrida dengan luas lahan kurang dari $5000 \mathrm{~m}^{2}\left(<5000 \mathrm{~m}^{2}\right)$ yaitu sebesar Rp. 63.994.614. Hasil tesebut diperoleh dari selisih antara total penerimaan petani dengan total biaya yang dikeluarkan oleh petani. Hasil analisis $\mathrm{R} / \mathrm{C}$ untuk cabai rawit hibrida dengan luas lahan $>5000 \mathrm{~m}^{2}$ nilai $\mathrm{R} / \mathrm{C}$ atas biaya total 3.98 dan nilai $\mathrm{R} / \mathrm{C}$ atas biaya tunai sebesar 4.00 maka dapat dikatakan bahwa usahatani cabai rawit hibrida dengan luas lahan $>5000 \mathrm{~m}^{2}$ menguntungkan dan efisien untuk diusahakan,karena nilai $\mathrm{R} / \mathrm{C}$ lebih besar dari $1(R / C>1)$. Sedangkan hasil analisis $\mathrm{R} / \mathrm{C}$ untuk cabai rawit hibrida dengan luas lahan $<5000 \mathrm{~m}^{2}$ nilai $\mathrm{R} / \mathrm{C}$ atas biaya total 3.33 dan nilai $R / C$ atas biaya tunai sebesar 3.32 maka dapat dikatakan bahwa usahatani cabai rawit hibrida dengan luas lahan $<5000 \mathrm{~m}^{2}$ menguntungkan dan efisien untuk diusahakan,karena nilai R/C lebih besar dari $1(\mathrm{R} / \mathrm{C}>1)$.

Hasil rata-rata tingkat keuntungan (Profitabilitas) cabai rawit lokal dengan luas lahan $>5000 \mathrm{~m}^{2}$ sebesar Rp. 104.256.202 dan hasil rata-rata tingkat keuntungan (Profitabilitas) cabai rawit hibrida $>5000 \mathrm{~m}^{2}$ sebesar Rp. 107.508.171. Jadi dapat disimpulkan bahwa tingkat keuntungan (Profitabilitas) cabai rawit lokal lebih kecil dari keuntungan (Profitabilitas) cabai rawit hibrida dengan luas lahan yang sama yaitu luas lebih dari $5000 \mathrm{~m}^{2}\left(>5000 \mathrm{~m}^{2}\right)$. Dari ke dua jenis cabai rawit lokal maupun hibrida sama-sama menguntungkan bagi petani cabai, namun tingkat keuntungannya lebih besar jenis cabai rawit hibrida ditinjau dari luas lahan lebih dari $5000 \mathrm{~m}^{2}\left(>5000 \mathrm{~m}^{2}\right)$. Hasil analisis uji Independent Sample T-Test diperoleh nilai $t_{\text {hitung }}$ sebesar 2.464 sedangkan $t_{\text {tabel }}$ sebesar 2.030. Dengan demikian nilai $t_{\text {hitung dibandingakan dengan }} t_{\text {tabel }}$ pada taraf signifikan $5 \%$ ternyata nilai $t_{\text {hitung }}$ lebih besar dari nilai $t_{\text {tabel, }}$ maka $\mathrm{Ha}$ diterima dan Ho ditolak, berarti ada perbedaan yang signifikan anatara tingkat keuntungan (Profitabilitas) usahatani cabai rawit lokal dan cabai rawit hibrida dengan luas lahan lebih dari $5000 \mathrm{~m}^{2}\left(>5000 \mathrm{~m}^{2}\right)$ bagi petani di Desa Gambangan Kecamatan Maesan Kabupaten Bondowoso Jawa Timur tahun 2017.

Hasil rata-rata tingkat keuntungan (Profitabilitas) cabai rawit lokal dengan luas lahan $<5000 \mathrm{~m}^{2}$ sebesar Rp.44.421.374 dan hasi rata-rata tingkat keuntungan (profitabilitas) cabai rawit hibrida $<5000 \mathrm{~m}^{2}$ sebesar Rp.61.361.855. Jadi dapat disimpulkan bahwa tingkat keuntungan (Profitabilitas) cabai rawit lokal lebih kecil dari keuntungan (Profitabilitas) cabai rawit hibrida dengan 
luas lahan yang sama yaitu luas kurang dari $5000 \mathrm{~m}^{2}\left(<5000 \mathrm{~m}^{2}\right)$. Dari ke dua jenis cabai rawit lokal maupun hibrida samasama menguntungkan bagi petani cabai, namun tingkat keuntungannya lebih besar jenis cabai rawit hibrida dilihat dengan luas lahan kurang dari $5000 \mathrm{~m}^{2}\left(<5000 \mathrm{~m}^{2}\right)$. Hasil analisis uji Independent Sample TTest, diperoleh nilai $t_{\text {hitung }}$ sebesar 2.419 sedangkan $t_{\text {tabel }}$ sebesar 2.030. Dengan demikian nilai $t_{\text {hitung dibandingakan }}$ dengan $t_{\text {tabel }}$ pada taraf signifikan $5 \%$ ternyata nilai $t_{\text {hitung }}$ lebih besar dari nilai

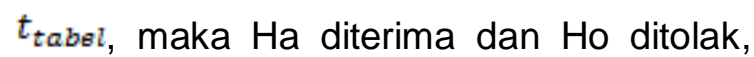
berarti ada perbedaan yang signifikan anatara tingkat keuntungan (Profitabilitas) usahatani cabai rawit lokal dan cabai rawit hibrida dengan luas lahan kurang dari $5000 \mathrm{~m}^{2}\left(<5000 \mathrm{~m}^{2}\right)$ bagi petani di Desa Gambangan Kecamatan Maesan Kabupaten Bondowoso Jawa Timur tahun 2017.

\section{SIMPULAN DAN SARAN}

Hasil penelitian ini menunjukkan bahwa Tingkat keuntungan petani cabai rawit lokal dan hibibrida dengan luas lahan lebih dari $\left(>5000 \mathrm{~m}^{2}\right)$ masing-masing sebesar Rp.104.491.148 dan Rp.107.443.650, sedangkan luas lahan kurang dari $\left(<5000 \mathrm{~m}^{2}\right)$ masing-masing Rp.45.917.770 dan Rp.63.994.614, dengan demikian terdapat perbedaan yang signifikan tingkat keuntungan cabai rawit lokal dan hibrida dengan luas lahan lebih dari $5000 \mathrm{~m}^{2}$ yang ditunjukkan dari nilai t 2.464 dengan nilai sig $0.049>0.05$, dan luas lahan kurang dari $5000 \mathrm{~m}^{2}$ yang ditunjukkan dari nilai t 2.419 dengan nilai $\operatorname{sig} 0.024>0.05$.

Berdasarkan simpulan diatas ada beberapa saran yang dapat peneliti ajukan yaitu. Untuk meningkatkan keuntungan dalam usaha tani cabai, petani harus lebih selektif dalam memilih varietas cabai yang akan ditanam dan menyesuaikan dengan permintaan pasar agar keuntungan yang didapatkan petani lebih maksimal. Dari hasil yang diperoleh tingkat keuntungan cabai rawit lokal dan hibrida dengan luas lahan lebih dari $5000 \mathrm{~m}^{2}$ ataupun luas lahan kurang dari $5000 \mathrm{~m}^{2}$ yaitu lebih menguntungkan untuk menanam jenis cabai rawit hibrida, karena tingkat keuntungan cabai rawit hibrida lebih besar dari tingkat keuntungan cabai rawit lokal. Untuk peneliti selanjutnya

hendaknya lebih memperluas lagi penelitian tentang tingkat keuntungan usahatani yang lain dan memperluas wilayah penelitian tentang usahatani karena semakin luas wilayah penelitian maka akan didapatkan hasil yang lebih kongkrit dari suatu wilayah.

\section{DAFTAR PUSTAKA}

Ahmadi. 2005. IImu Usaha Tani. Jakarta: Penebar Swadaya.

Daniel, Moehar. 2004. Pengantar Ekonomi Pertanian. Jakarta: Bumi Aksara.

Fauzi, Y, Yustina E.w, Imam S dan Rudi H. 2008. Kelapa sawit Budi Daya Pemanfaatan Hasil \& Limbah Analisis Usaha \& Pemasaran. Edisi Revisi. Jakarta: Penebar Swadaya.

Gustiyana. 2004. Analisis Pendapatan Usahatani untuk Produk Pertanian. Jakarta: Salemba empat.

Hansen \& Mowen. 2004. Manajemen Biaya, Edisi Bahasa Indonesia. Buku Kedua. Jakarta: Salemba Empat.

Hernanto. 2009. IImu Usahatani. Jakarta: Penebar Swadaya

Koyan, I Wayan. 2012. Statistik Pendidikan. Singaraja: Undiksha Press.

Shinta Agustina. 2011. Ilmu Usaha Tani. Malang: Universitas Brawijaya Press (UB Press).

Siregar, Syofian MM. 2011. Statistik Parametrik Untuk Penelitian Kuantitatif. Jakarta: Bumi Aksara.

Soekartawi. 2005. Ilmu Usaha Tani dan Penelitian Untuk Pengembangan Petani Kecil. UI - Press. Jakarta.

Soetriono, Suwandari, Anik. dan Rijanto. 2006. Ilmu Usahatani. Edisi Revisi. Cetakan Kedua. Jawa Timur: Bayumedia Publishing. 